Historic, Archive Document

Do not assume content reflects current scientific knowledge, policies, or practices. 



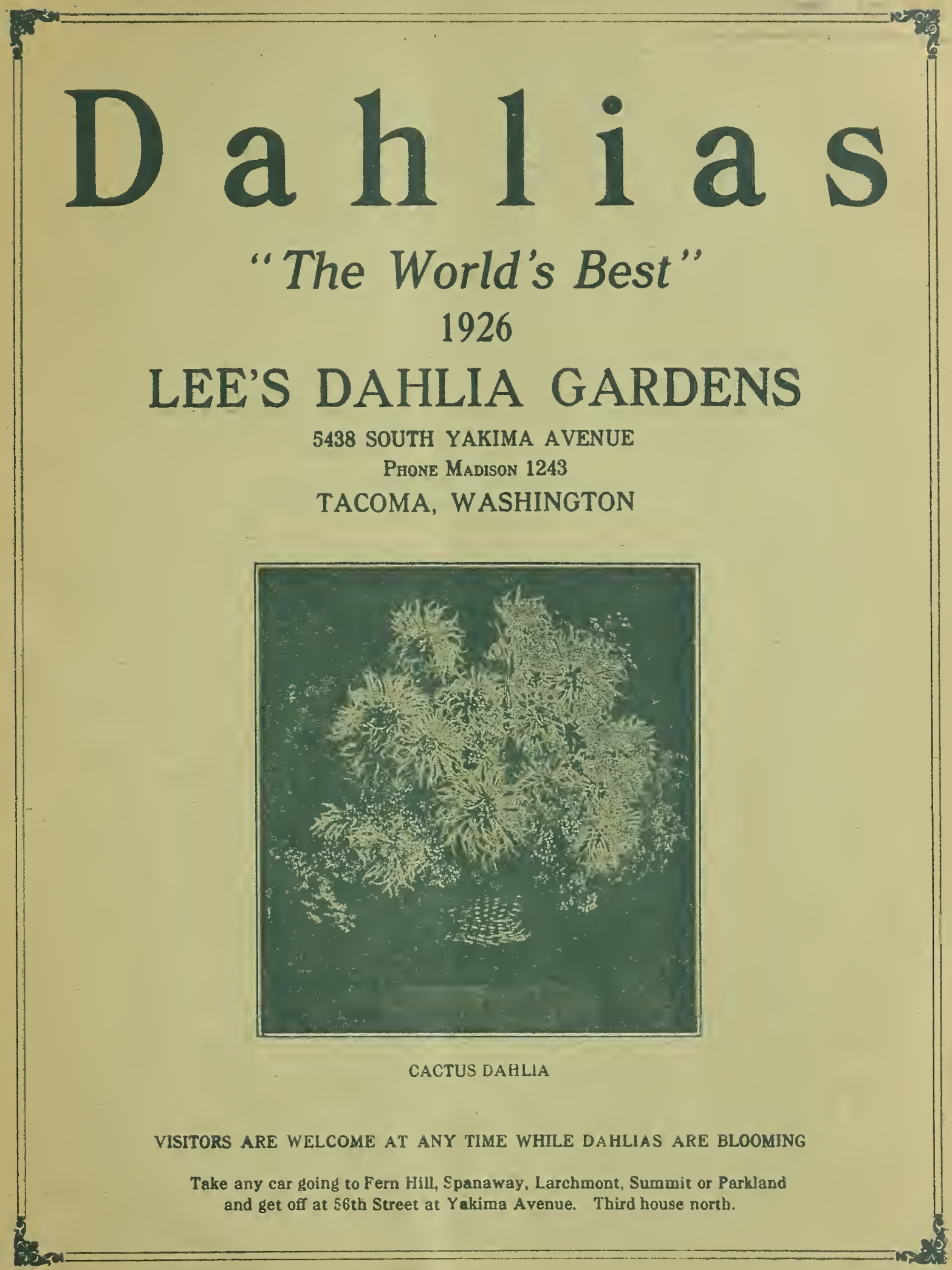




\section{GREETINGS — INFORMATION}

AT THE BIG NORTHWEST DAHLIA SHOW, GIVEN BY THE SEATTLE DAHLIA SOCIETY --- WE WON NINE RIBBONS ON NINE ENTRIES, WHICH WON US THESWEEPSTAKE TROPHY OUR DAHLIAS WON MANY PRIZES FOR OTHERS IN ALL PARTS OF THE COUNTRY.

We appreciate your orders and wish to thank you for the many kind letters received, telling of the success achieved with our bulbs; also thank those who so kindly recommended us to their friends.

TRLAL GARDEN-Our own introductions and all new varieties from all parts of the world, are planted the first year in our trial garden and their habits carefully noted and only those of outstanding merits are listed in our catalogue, and many are discarded each year, because their habits do not come up to our staridard. Our planting stock is carefully inspected both before planting and while growing and any which does not look healthy is destroyed.

GUARANTEE-Our bulbs are strong and full of "pep" and we guarantee every bulb we sell to be true to name, and we will gladly replace any mistake; also guarantee each bulb to have live "eye" or sprout and if planted right and given proper care we are sure will grow. Please notify us at once if a shipment should arrive in unsatisfactory condition.

ORDER EARLY-Orders are reserved in the rotation received and ordering early will avoid disappointment.

SUBSTITUTIONS-We do not substitute unless instructed to do so. Please give a few second choice, especially if ordering late.

SHIPPING-We send out all orders paid for between April 15th and May 1st unless you specify a later date. Orders shipped before April 15th at purchaser's risk.

TERMS-Cash with order. No order sent C. O. D. unless 50 per cent of purchase price accompanies order. A deposit of 25 per cent with the order will reserve the bulbs for you and balance must be sent before shipment. Orders not held after May 1st unless paid in full, unless by special arrangement.

POSTAGE-We pay postage on all retail orders of over $\$ 1.00$. Orders of less than $\$ 1.00$ add 10 cents postage. If you wish the bulbs insured add 5 cents for insurance.

WRITE YOUR NAME AND ADDRESS PLAINLY.

REFERENCES-National Bank of Tacoma and R. G. Dun \& Co., Tacoma.

We wish you all a HAPPY NEW YEAR. J. W. and Mrs. J. W. Lee

\section{Those marked with stat $\star$ are Northwest introductions.}

Address your letters to

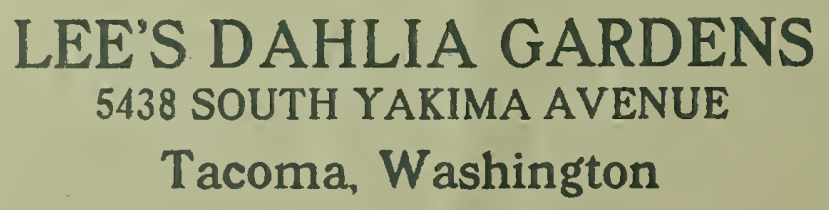




\title{
New Dahlias for 1926
}

\author{
"Our Own Introductions
}

Carmona: (H. (†)-Fine incurving petals, free blooming on splendid stems. Clear rosy carmine cerise; a striking color, and large flower _.

Nesika (Dec.) - Large flowers on good stems; free blooming; color crushed strawberry with buff suffusion and blending toward center of soft crimson, making a beautiful flower, and something new in color

Ladty hove (H. C.) - A beautiful combination of buff and canary yellow tipped white; has good stems, large size, and free blooming- 3.00

\section{WORLDSUHST NEW AND STANDARD I MRIFTIES}

In describing the types of Dahlias listed, the following abbreviations will be used: Cactus (C); Hybrid Cactus ( $\mathrm{H}$. C.); American Cactus (A. C.); Decotative"(Dec); Peony (P); Show (Sh.); and those with our name (Lee) following name of variety, our own introductions. Those marked with star are Northwest introductions.

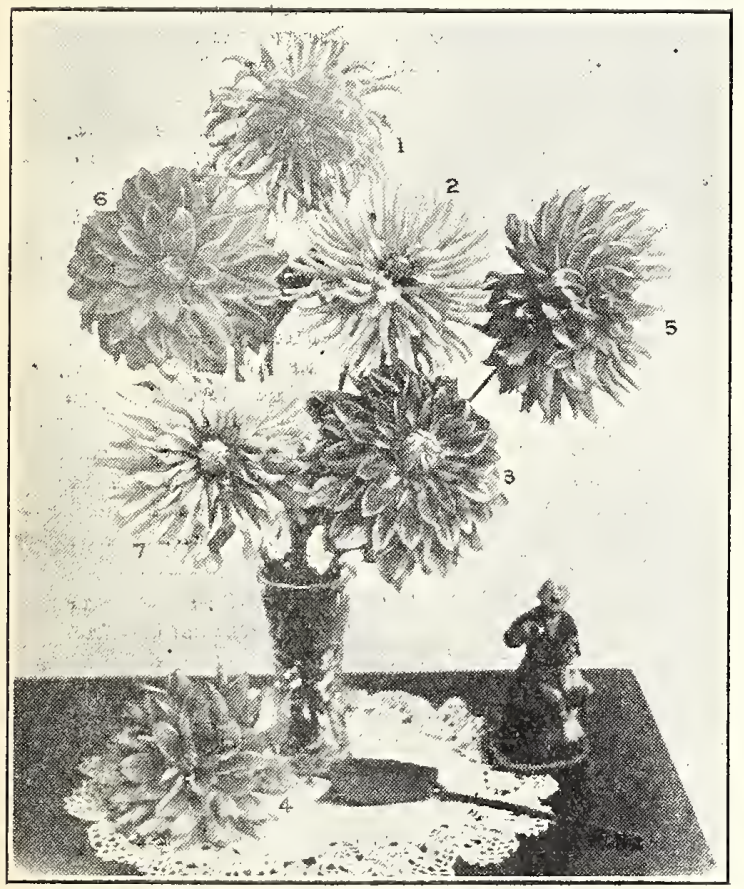

1-Adah Pomeroy. 2-Alphonsine. 3-Alvin Ii. 4-Ethel Class. 5-Glady's Eleanor. 6-Lehil. 7--Silvery Moonlight.

* ADAH POMEROY (Cactus) (Lee) - A beautiful targe flower with graceful incurving petals; color: a delíghtful shade of old rose blending to gold at base of petals; reverse of petals tinted with mauve. A Dahlia with good habits and splendid stem. Won 1 st prize as best rose cactus $1925 \ldots \ldots \ldots$ _. $\$ 3.00$

* AlaNNah (Hybrid Dec.)-Color a deep rose pink shading into picnic yellow at base of curly reflex petals; profuse blooming and a splendid keeping eut flower on good stems ---_-_-_-_-_._--_-

*ALPHONSINE (Cacrus) (Iee)-Good white Cactus varieties are scarce, and we are proud to inroduce this one. The bush grows tall and carries a profusion of lovely blooms on long upright stems; perfect form closed centers; color white with faint tinge of cream which is deeper at center. Buds when opening tinged with mauve, which turn white as flower opens. A splendid Dahlia and good cut flower-_-_-_-_.--

*AlWIN R. (Dec.) (Lee)-An extra large deep flower with long strong stems which holds its bloom aloft and looks you in the face. The color is a velvety amaranth purple, blending to tyrian rose with halo of deep yellow at base of petals, making a very beautiful flower

A.IBASGADOR (H.C.) - Soft yellow butf, shaded salmon pink: fine form, very large. perfect stems, excellent keeper and strong grower. Sometimes comes with open center - - - - - - - - - - -

M.MER GLOW (cac.) - A bright yellow, deepening to pale orange at the center. The petals are long, narrow and straight. An exhibition and ent-flower variety _._._._.

*MOLITS (H. C) (Dutton's)-Very large tree blooming, on splendid stems; color a beautiful salmon pink _..._-_._-_._._.

* IRCTIC (P.)-Pure white; most perfect in form, immense size; nine inches or more in width, yet fluffy and graceful, very long and strong stems holding the flower well above the foliage_..--

I:ALLET GIRL (Cac.) - An attractive new California Dahlia of very odd coloring. An extra large, deep flower, made up of a mass of narrow incurved petals, which are pure orange, white with orange base and various combinations of these colors on same bush. Free flowering; stems pendant_---

BETTY AUSTIN (H. C.) - The color is yellow at base of petal, blending to carmine and rose; a good medium-size flower on a good upright stem. A beautiful cut flower.---

* BIILY MorgaN (Peony) (Lee)-One of the brightest in our garden; color scarlet red blending to deep yellow at base of petals and tipped pure white. Flowers of medium size on good upright stems and very free blooming. Bushes medium height; a good cut flower 
WL ICK DIAMOND (Sh.) - Large flowers of deep maroon, nearly black; fine for cutting or garden decoration; good stems___-__-_

boxily G. (American Cac.) - Pure, soft pink. Strong grower, producing its large blooms well above foliage in great profusion. With all lovers of pink dahlias, this wondertul new variety is bound to be a great favorite

BORDER KING (cac.) - Large scarlet on good stem and very free blooming

IBOB VHWComis (Dec.) -Deep royal purple, large tlower on good stem

('AlBkI (English Dec.) - Rich pink shading lishter to center; large full flower on long erect stem; tree blooming; very good

CMLAORNA HNHANTRES (H. C.) Large, blooms of great substance and of a delightful shade of pale pink. Erect stems and a very profuse bloomer. Perfectly lormed

cAlimexclet (Dec.) - Clear yellow, distinctly penciled with bright scarlet. Very beautifully formed flower of immense size. Fine stems and a kood keeper; compact habit and free bloomer................

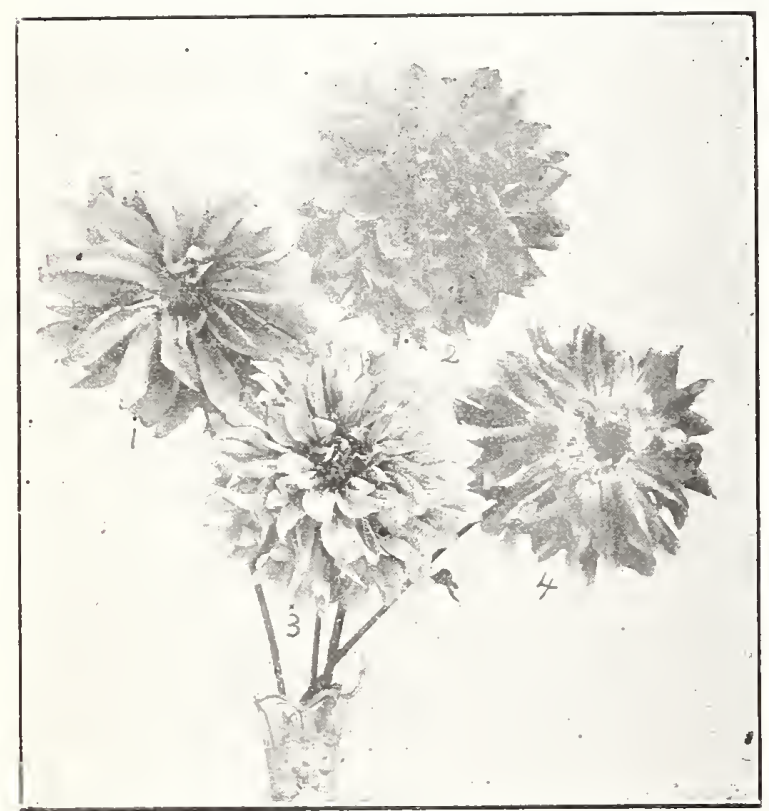

1-Carrie Menzel. 2-Centralia. 3-Celia E. Harris. +Puyallup.

C'Alille MrN/WL (Isee) (I')-One of our 1924 introductions. A beautiful soft salmon pink with an apricot sheen. Flowers are large and upright on extra long strong stems; very profuse blooming and one of the best for cutting. as it is a splendid keeper
('ELIA E. HARRIS (Lee) (H. C.)-OUF 1924 introduction that won for us the silver cup for best pink $H$. C. or Dec. at Weatern Washington Fair, 1923, with many other splendid varieties in competition. A perfectiy formed Hybrid Cactus and a beautiful shade of bright pink, having a llight tinge of mauve. The blooms are very large and full and the stems are perfect. An extra good dahlia in every way _.......

(NNTHALIA (Lee) (Dec.)-Another of our 1924 introductions. Very large flower on extra long, strong stems, 24 inches and more in jength. A splendid keeper as a cut flower. Color dark crimson, blending to finelleall Brauty red

(HAMPAl. :'Mec) - One of the largest dahlias glowh cuior is rare and delightful, stem is strong and nu,ds the massive flower absolutely upright an. .we bushos are plentiful producers of blooms. Coloring is a dull golden champagne, raryine to chamois

(HANSOX (P.) - The color is deep lilac with a bluish sheen. A large full flower on a splendid stem

CHAli.l (Marean Dec.) - A very beautiful autumn coloring of yellow and burnt orange; good stens and blooms freely

chelili HILL (Dec.)--Large pink scarlet, penciled with crimson: free blooming; stem good

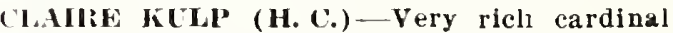
red shaded with garnet and bright yeliow at base of petals, whlch sets off the red most effectively. A very beautiful flower on splendid strong tsems

IGAliETTE (H. C.) - A new California hybrid cactus more vividly colored than Ballet Girl, and we believe equally as good in its class. Best descrlbed as creamy white, heavily edged orange, but no two flowers are exactly alike. Bloom is large and of good substance. Stems are of the best quaiity. Good for all purposes. Very much in demand during the garden season and every visitor commented on its beauty and oddity - - - - - - - - - -

$\Rightarrow$ CITY OF PORTLAND (P)-One of the grandest new peony. The blooms are often 8 and 9 inches in diameter of very artistic form. Color is a clear, rich, deep yellow. An ideal cut flower, having long, strong stems and good keeping qualities. Strong. vigorous growing plants produce flowers freely

CONQUEST (Cac.)-Large crimson maroon; strong stems and very good.

('ORAL (Cac.) - A large flower of deep coral pink; petals very full and incurved; has splendid stems_

Notice-Please give a few second choice in your order in case we should not be able to supply. first choice, as we do not substitute unless notified to .75 do so. 
DADDY BUTLER (H. C.) - The color is of the American Beauty rose shades, or rosy carmine. The reverse of the petals is a lighter tint, giving a variation of color. We know of no other dahlia like it. Stem is perfect and we never grew a dahlia which was a heavier producer of blossoms from the start to the finish of the season. We all know there are perhaps six dahlias which will last a week when cut, and this is one of them

DAKOTA (Dec.) - An eastern Dahlia of splendid merit. Flame color; very large flower on perfect stem; vigorous grower; splendid for garden or exhibition

DICTATOR (Dec.) - Lavender rose, suffused with fawn; very large chrysanthemum-like flowers on long perfect stem; very beautiful 1.00

WOROTHY HOBHINS (Dec.) -One of the finest of the autumn shades; large blooms of deep buff suffused with orange; splendid stems

IREER'S YELIOWW (Sh.)-Quilled; often 7 inches across strong : tems; clear yellow

IR. H. TEVIS (Dec.) - Odd shade of old rose, suffused with gold and shaded apricot. An immense flower, wrect on long, stout stem. Will sometimes sport single blooms

FARLF WILLAMS (Dec.) - This is new giant flowering Dahlia; we having grown it as large as 12 inches in diameter. The colors of brilliant crimson and white are well distributed. Plants are very free in bloom. This is one of the finest and most attractive Dahlias ever introduced. Strong stems

EDITH CAVELI, (P.)-Very large full flower, old gold shaded reddish bronze; Iong, strong stem

EI. GIRANADA (H. C.) - A new California Dahlia that is a prize winner. An extra large vivid orange bloom, and the petals twist and interlace, showing at the tips a creamy yellow reverse. A Dahlia with splendid habits and perfect stems. Net_-_ 10.00

EI. JEBEL, (H. C.)-A very showy flower of scarlet and zold. Iarge size on good stems, free blooming

ELIZABETH BOSTON (P.) - The best and biggest peony of its coloring that has so far been produced. Enormous blooms of deep crimson, shading to old gold at the tips, and will hold its color the entire season. The center is surrounded with tiny, curly petals which make this introduction perfect of its type. Stems are exceedingly long and cane-like. Tall growing and very กิeriferous

- hLIZABETH WHITE (Dec.) A giant size, but a very graceful tuffy nower on good long stem; the color is soft buff suffused with soft coral and salmon pink; a very pleasing hower, very profuse blooming

EISIE DREXLER (H.C.)-A deep velvetr maroon bloom of huge size. on splendid long trong stems
EISIE OLIVEIR (H.C.) - A very large creamy pink on good stems; profuse blooming; a very beautiful flower

ENCHANTRESS (Holland Dec.) - Color a sil very pink, being absolutely free from any lavender tint; long, narrow, graceful, wavy petals. A very dainty flower of niedium size on long stems

FTHEL (Cac.)-Large incurved. Soft pink blended to white center; good stems

ETHEL BURNHAM (H.C.) Color is a lovely shade of deep old rose; a profuse bloomer. Elowers are very large, stems fair

75 *ETHEL (IASS (Dec.) (Lee)-A mediumsize cut flower of salmon rose blending to yellow; petals tipped lightly with gold. Very free blooming on splendid stems _-_-

E'THEL M. (H. (') - One of the very largest blooms of great depth on strong erect stems; color a beautiful amaranth pink 75 blending lighter at tips. Scored 88 in $\mathrm{A}$. D. S. trial galden at Storrs, Conn.

.5 ExMOUTH GLORT (Dec.) - Large, yellow and orange, tipped deep with white: a beautiful flower; some blooms come solid color white or orange; needs some disbudding, as it is inclined to grow bushy; stems are good.

WhaNeIs LOBDEI, (H. C.) - A large mallow pink, blending to white at center: very nrofuse blooming: stems are strong and erect but need disbudding for length; has been a prize winner many times in the east 2.50

FRAL G. S(HIS (bec.)-Beautiful blending of chanoise and orange yellow, with reverse of coral red: perfect stems _-_._-

F. W. FFiLows (cac.) - Very largo: bright orange; long narrow petals; good stems

GARDF. GLo (P.) - An extra large full flower of rich bright relvet scarlet on long strong stem

GFE WHIY (H. C.) - Very large; soft buff shaded with salmon. An extra good flower on good stems _...-

GFO. W. GHLO (Sh.) - A lovely large bright pink, perfectly quilled on extra good stems

GEORGE WMITHR (H. C.) - One of the largest and best varieties to date. Salmon pink suffused with gold in the center; is a wonderful bloomer with long, stout stems. will always be a leader and in great demand

*GWO. W. WRIGHT (Dec.) — A new large decorative of heantiful glowing salmon with zolden sheen; reverse of petals tinted manve. Perfect form and has splendid stems

GINT IIUBY (Dec.) - A beautiful vivid red, large flower with good stem; profuse

blooming; a new eastern dahlia
(ila DYS BATWS (American Cac.) Immense. heary blooms of soft tan color, tinted with rose; perfect stems and a profuse bloomer 1.00

* GIDUS ELFANOR (Hrbrid Cactus) (Lee) - An extra large flower on a perfect stem: 
a full graceful bloom of clear canary yellow without any shading. We think this the best Free blooming on medium height bush.--

GLORY DE TrON (Sh.) - Targe pure white; round as a ball; strong stems

GLORL OW NYKink (P.)-Large purple shaded maroon; full flower; on good stem

GLORY OF NEIV HAVAN (Dec.) - A soft pinkish mauve, a color quite distinctive and beautiful. long stemmed, large blooms; excellent for cutting

(:OLI) MEDAI (Sh.) - Deep canary yellow striped and tipped red; very free blooming on good stems

GOLDEN WHAT (H. C.)--Without doubt one of the very finest Hybrid Cactus. The large blooms are held erect on strong long stems; bright orange-buff color; a leading cutflower

GOLDWN WHST (Sh.)-Large; light yellow; notched petals; good stems

GORGHOC' (P.) - This is a wonderful dahlia because it has tremendous size, great depth, stiff long stems, and will bloom freely throughout the season. Late blossoms will be as large and good as the early ones. The color is yellow, shading to bright

GRAND DLCHKsis MARIA (Sh.) Latge, soft buff overlaid with orange, reverse shaded bink

GREAT IBITTAIS (Dec.) - Depe mauve or lilac, distinct form and large size, fine for cutting; good stems _...___________-

GIRIST'TE (H. (') - Very large deep flower of beautiful old gold with a light tint of pink; stems good; profuse blooming--_--

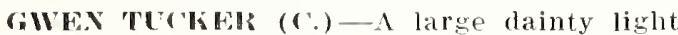
pink on good stem

HELEN DURNBACGH (HI. r.)-Immense flowers of delicate blush, deepening at the center; this will become a creat favorite; stems good

HUCH McNEAI (rac.) lovely shade of lavender pink, very fine for cutting; good stems

*H. IT. IV AlliblR (I.ee) (H. (')--One of our own introductions; large; bright yellow; frep blooming; fine stem

IXSUINIBE: (Holland Decorative)-One of the most wonderful yet introduced; extra large flower with broad, wavy petals and long, strong stems; brilliant golden orange color

*IVOIRH (P.) ...The waxy petals of great substance are long and pointed and curl and twist in such a manner as to almost cover the center; color is clear, glistening ivory, deepening to cream at base of petals and has a faint glow of buttercup yellow at center: an extra large beautiful flower on strong 18-inch stem

JOHN HALIDNG (Marean H. Slu.)-Deep heliotrope, large hloom on good stem

JEAN CHAzO'T (H. C.-A very beautiful French dahlia; color autumn shades of golden bronze suffused with nasturtium red, splendid stems, profuse blooming and good cut flower

J EIRSEY's BEAUTY (Dec.) One of the most beautiful true pink dahlias we have ever grown; a clear rosine pink, very large, of perfect form on long erect steni, has won many gold medals and prizes, and we heartily recommend it

JERSWY's boveriglin (bec.) - A new shade and hard to describe, but we think it a salmon orange; flowers of good size on good stems --_-_-_'-_-_-

"ONKHFER BORFEL (Holland Dec.) Ali elegant large flower of bionzy buff-yélow color; a clear and most'beautiful shade. Strong, upright grower and long stout erect stem --

IUDGE ALTON IB. PARTER (dasten Dec.) - Bronzey golden buff; flowers are large, splendid form; stenis good sis are

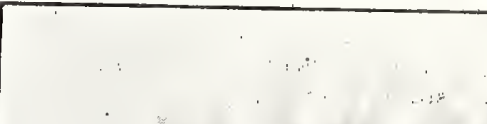

\section{0}

0

50

. 
that should be in every collection; we have good reports on it from all parts of the country

IÁLA (H. C.)-Very large Hybrid Cactus: pure scarlet; extra strong stems

Kathryn Donges (H. C.)-Light sulphur yellow; a large flower on good stem; flower looks very much like Yellow King, but makes much nicer bulbs

RING ow shows (sh.) -Deep butter yellow of a solid color throughout. Every petal is most perfectly quilled and uniquely formed. A mammoth flower, on long stems

Koh-i-noor (H. (.)-Dark maroon red; a large velvety bloom on good stem; plotust blooming

LADY BETCY (Dec,)-This beautiful new dahlia is an extra large finely formed flower, produced freely all season on long, stifl, erect stems. A lovely cleamy white artistically suffuserl with pink, reminding one of a bush of pale pink peonies in full bloom_ 1.60

LA FAVORITA (Hybrid Cactus)-Grand new dahlia of distinct cololing. Beautiful brilliant salmon, shading darker in the center and lighter at tips. Of perfect form and carried trect on extra strons stems; idfal cut flower

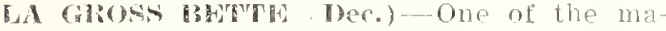
rean dahlias; a deen crise; large size on splendid stems

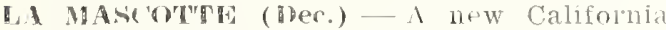
dahlia that is gland. Tmmense fowel's of a very distinct colol, silvery white with light violet reverse. Myriads of blooms hell erect on excellent stems_______-_._._.

* La Sorita (A. C.) - A lovely old rose with suffusion of marve; large size bloom on good stem

* L B color which we find hard to describe and the best we can tell you, it is an aplicot orange overlaid with golden irridescent sheen: there is also a flush of old rose, more on the reverse of petals. Each petal has a pin line of gold around the edge. The blooms are very large, graceful and full and carried on long strong wiry stems. A generous bloomer on medium height bush This beautiful flower has been greatly admired and praised in our garden

MABFI THATCHER (Der.) - Large flower of pale yellow; stems fair very large incurving petals and good stems

* MARCELLA GILI (Dec)-A delightful clear soft pink, variety that is bound to become a great favorite with everyone, especially florists. A wonderfully free bloomer on long, individual stems, that hold the blooms rigidly erect. Very perfectly formed and is second to none in keeping qualities when cut

MARIPOSA (H. C.) -A beautiful lavender pink; a very large size on good erect stem; free blooming
MMRON CHRISTIN (Der.) - A light creamy yellow tipued rose; large flower on good

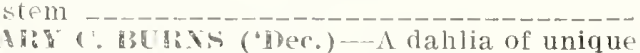
colorins. The outside of the petals are old gold and the leverse a dull red, forming a beautitul combination of gold and red. have flowers and sood stems _._-___-_-

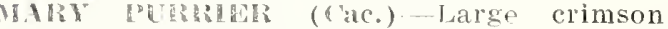
scal'let on strong, elect stents

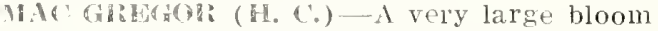
on strong erect stem; color, a spectrum red with lemon yellow at base of petals, a very heautiful flower and a prize winner.

MHLOD ("ro) -Large; cleal yellow tipped white: incurvor petals; sometimes blooms all yellow

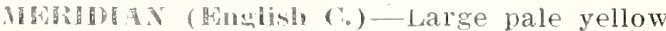
bloom on cood stem; profuse blooming..

MHEGOll (Sh.) - Bright ruby red, large size on good stems

MPTHBHER (".)-Dark crimson, suffused nurple: one of the largest Peonies grown; strong stems

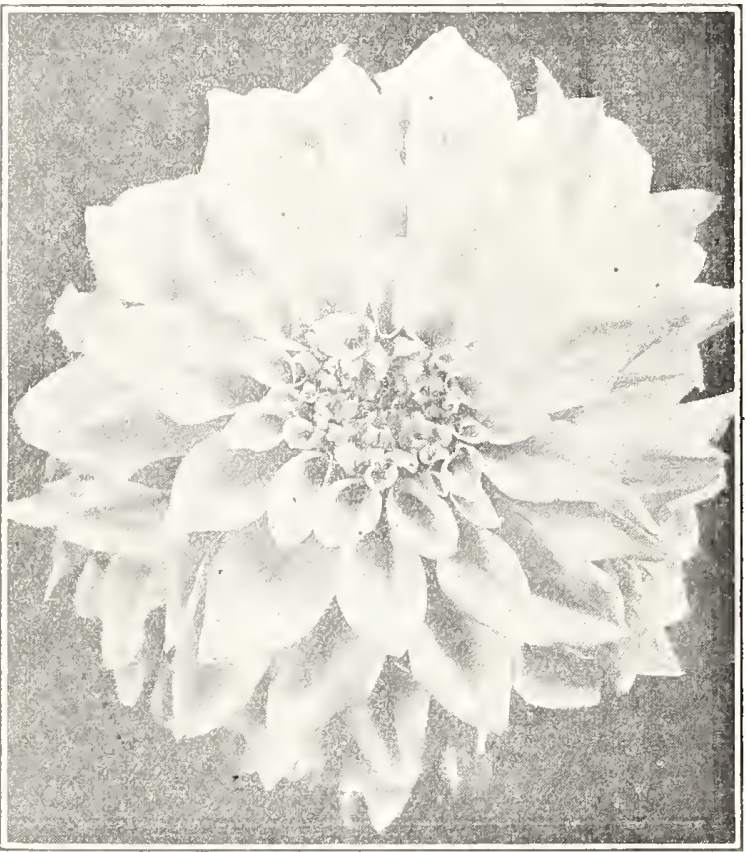

1.50

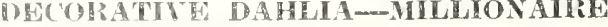

MILUIONAIRE (Dec.)--One of the largest dahlias in existence, with short stout stems. Color is light lavender, shading to white in center

HODEL (Cac.) - Yellow glound, shading to lovely pink, tipped yellow; beautiful incurved form and fine stems _-_-_-_._-

.50 MES. CMRL SALB.MCH (Dec.)-Immense blooms of a lavender pink color, on exceptionally strong stems, a pelfect exhibition and cut-fiower variety; one of the best.-- 


\section{SPECIAY, OFHELS}

Uur selections 111 Correctly habled For $\$ 2.50$ we will send 12 Pompon varietic For \$3.00 we will send 12 good varieties. For \$ 5.00 we will send 12 extra sood var"eties For $\$ 10.00$ we will send 12 fine exhibition Dahlias For $\$ 15.00$ we will send 12 extra fine exhibition For $\$ 25.00$ we will send 12 of the new highelmiced varieties.

Selections left to us will be senerously dealt with, and only the better varieties will be sent; and our liberal filling of the order will more than be satisfactory

Mlit. ('. (o)l'hli (Cac.)--Cream. sulfused salnien: very large; stems fairly good _...

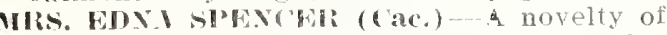
a delicate and evouisite shade of lavender or orchid pink. In imuch demand, as it is a lasting cut-flower. plofuse bloomer on good stems

MHS. HTHEL F. 'T. SMLTH (11.1.) Cleamy white Hybrid Cactus shating to a lemon tint in the center. This is one of the larsest dahlias I lave orown: it is a profuse bloomer, and the Howels ate held far above the foliage on stronm strum. Won the first prize at Oakland, Cal, for largest flower in show

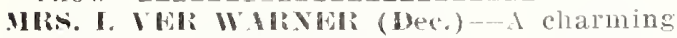
deep nauve pink or cattleya (orchid) color. Extra strong s.ower. producing its gigantic blossoms freply and risidly elect on long. cane-like stems. Was the centel of attraction in our show garlen and wherever exlibited

MIRS. W. H. FATW (H.(?) - Best and largest white Hybrid Cactus Dahlia we have "vel" seen. Blooms mofusely on long stiff stems

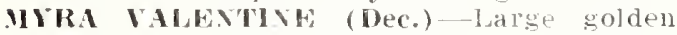
bronze suffused salnon; good stelm and free blooming

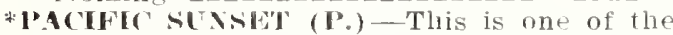
largest dahlias grown and color is a pleasing blend of golden yellow and soft salmon red: an ideal autmon shade and a free hloomer. It is also the most fragrant of any dalilia we have glown end always attracts great attention in the garden ol on exhibit; stem good

PIRADISH (H. (') Very large: color dull sold with suffusion of rose; stems good...

Parbir O'Mali. (Dec.) - Awarderl the Amprican Dahlia Society's Fold Medal for best variety in 1920. The colol is an unuswally soft ant pleasing shade of orangebuff. The immense flowelk ale bolne on lons, strong stums, held rigidly erect. One of the most lasting cut-flowel dahlias ever introduced

PATIRO' (Cac.) Glorious bright scarlet fowers of most perfect cactus folms, produced in ereat profusion; fine stout stems; admirable for cutting

PAII. MICHAL (Dec.) One of the largest Dahlias grown; a beautiful old gold with hronze shading; stems are fair; bushes are al ays loaded with blooms
I'EARI HUGGLES (I'.)-Bright carmine pink suffused with liglit pink _-_-_-_---

I'LRRE LE BLOUD (Dec.)-Dark red at base, distinctly tipped white; large flower on good stem

POIAL IBEAR (Dec.) -Immense pure white bloorns whicis are held on long straight stems, are of sreat depth. The habit of this variety is all that can be desired and the buslies are continually loaded with bloom. Its kueping qualities are of the best, which makes this flower oll : the best for florists" use

POLAR s'TAR (P.) - The purest white dallita of remarkable beauty. Flower is lare and full and carried on 18-inch stems. 1. white dallia it is unsurpassed both in al. pearance and free blooming

PRIDE OF CALIFORNIA (Dec.) This is the best red decorative fol all purposes. It has size, stem and splendid keeping qualities when cut. We can cheerfully rommend this Californian

MHDE OF WMYN (Dec.) Color is a deep plum purple; flowers large on good stems.

hiDIO (Ded.) - A true giant size; color blood red and tipped yellow; a flower that attracts immediate attention; flowers have sreat depth as well as width and ale held erect on strong stems - - - - - - - - - - - - -

lioblot 'rikit (Dec.) - American Beauty Rose color; perfect formation and has splendid strong. erect stems; one of the lrize winnel's of the east_____.

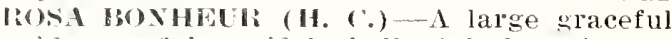
bloom of beautiful shell pink blending to ivory white af center; free blooming and has splendid stems _-_-_-_-_-_-_-_-_-

75 lioshlilWR (Dec.) - Soft rose pink; very lalog, on long straight stems; sometimes take peony form 2.00 SICAMORE (Dec.) Color a golden yellow shaded with amber at center: large blooms on splendid stems; one of the big prize winners in the east _...-

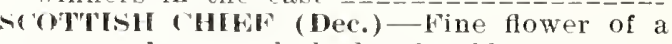
new and unusual shade of golden cocoa or an amber coloring; sometimes the blossoms are tipped with white deepning into pink; stems long and strong

SlAHORSE (II. (.) English novelty of Hybrid Cactus type. Color golden-yellow with pure white tips which extend half way lown the petals. One of the most attractive grown

SWNORII (Dec.) - One of the largest dahlias srown; a rich dark red, with good stems: a new one that will be a favorite..

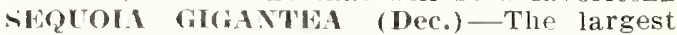
deep yellow decorative dahlia to date; noted for its vigor. productiveness and all the other fine qualities _-_._- $-\ldots--\ldots---$

sHCDOW's MANEDER (Dec.) - The best

$$
\begin{aligned}
& \begin{array}{l}
.75 \text { lavender decolative to date; very large } \\
\text { flowers on long, stout stems; a beauty }
\end{array} \\
& \text { low and soft orange; one of the most beau- }
\end{aligned}
$$


tiful we bave ever grown. millites blooms come solid yellow. It a perfect Hybrid Cactus having long na. low, gracetul, curlíng petals, and full cli d centers. The bloon a are very large anu stems are perfect; bus grows medium height and produces bo.nus with great freedom --

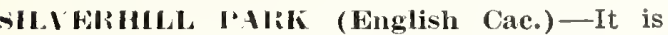
massive in size, beautifuuly incurved in form and with perfect center; color is a glistening white; the plants are strong and stems are good _-_-_-_-_-_-_-_-_-_-_-

SOLDIER BOY (P.) - A new Oregon peony that is distinctly different; large flower of khaki colol with reverse of petals a deep rose; profuse bloomer, stems not very upright

SOldDIER'S LASS (Cac.)-Enlliant red tipped white, very showy, on good stem; a beauty

SOUTH PORT PRIDE (Dec.) - A new Eastorn dahlia that won certificate of nerit at American Dahlia Society's trial gardens, also at California trial gardens; a splendid new variety; color primrose yellow deepen ing at center to canary yellow and ends $u$. petals flushed with lavender; a very large flower on perfect stem

*S'T. ELIAS (Cac.) - This is a pure white cactus dahlia with slightly incurved, clawshaped petals. Flowers are large and produced freely on fine stems: highly recommended

ST. LEONARD's (English Cactus)-Color at base and halt the lengtl of petals is a beautiful shade of yellow, balance of petals and tips is a bright scarlet; flower's stand boldly erect and are very hardy, being the last to be cut down by frost

SURPIISE (H. C.) - Rich orange amber. bright yellow center, fine habit and good stems

SUZANXE CAYEUX (Cac.) Beautiful large creamy white; free blooming; on good stems

SWEETHEAR'T's BOUQUET (P.)-Unique shading of salmon rose, shaded with fawn; pleasing alike in both day and artificial light; flowers are very large, and stems extra long: one of the very earliest to bloom and continues throughout the season

SYDNEY JONES (English C.)-One of the best cactus dahlias grown; very large full flower: fine petals and stems perfect: color a soft rose pink with tint of lavendel and shading to tan gold at base of petals; very free blooming

*TACOMA (Lee) (Dec.)-One of our own introductions; very large full flowers of good form; a beautiful yellow suffused with scarlet and gold; a seedling from Geisha and similar in color; good stem and free blooming: very much in demand.

TANGO (Dec.) - Showy orange bronze: a distinct and very attractive color; large, very double flower with pointed petals; long, stout stems and strong, upright growth; lasting when cut

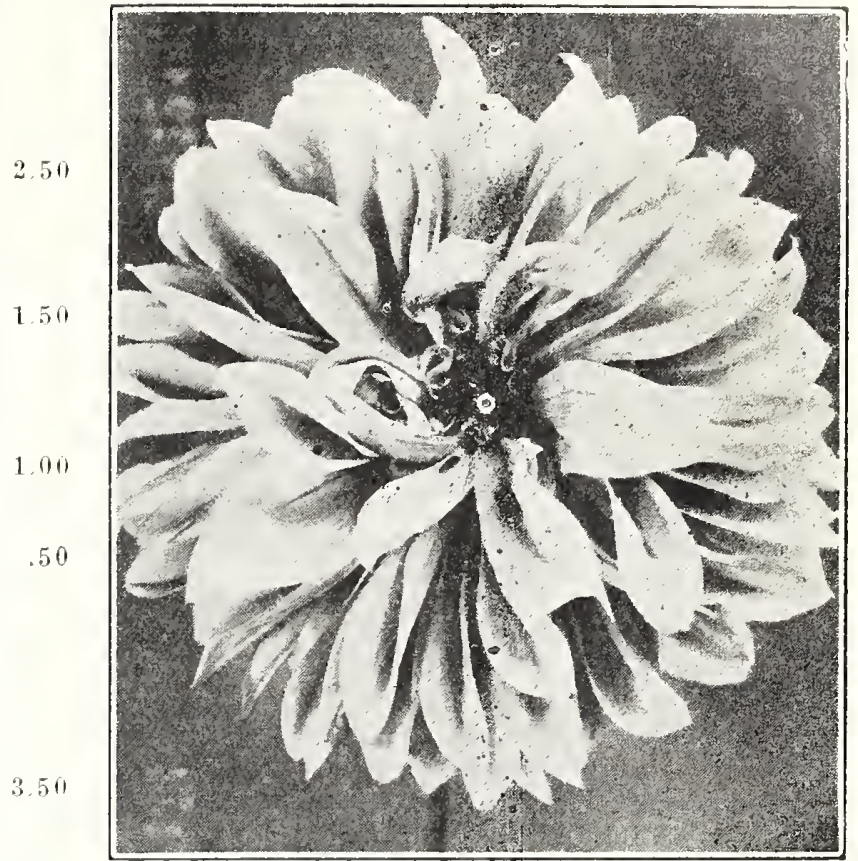

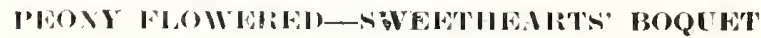

TEIIACHIII (H. (')-Very large flowers on good stems; color bright canary yellow; a very good dahlía _._._._._._-__.._-_-

'THE LII" (Cac.) - Long, narrow incurved petals, maroon shaded, almost black; good wiry stems

THE GIANT (Bng. Deony)-An enormous Hower on long stem (18 in. long or more). color deep crimson

THA GRIJZIS (Dec.)-A lare novelty of deep, rich crimson-maroon, on perfect stem. Of inmense size and a prolific bloomer. lowers are of very attractive formation and create a sensation wherever grown_--

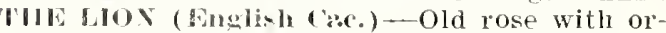
ange shading at center; large size on good stems

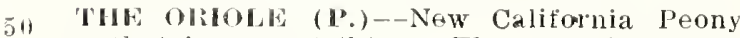
that is very striking. The color is a combination of burnt orange. red and yellow, many of the flowers shading to white at tips. Vely larg full Howers on good stems 2.00 .50 .56

'THE PEQTO' (Dec.) - An extra large dahlia of clear scarlet; stems are good; a very attractive flower _._._.....

'TOM LUNDY (Hybrid Cactus)-Bold rich crimson flower often 9 inches across and generally quite double in the center. Free, constant bloomer

InIMY ATKNs (Dec.) - A new Califormia dahlia. A startling flame scarlet with a metallic lustre that glistens in the sunshine. The flowers are large and held erect on strong sterus 
TOM PETEMAN (Dec.)-Large full flowers. Outside petals rich bronze; inside petals bright golden yellow, sometimes tipped white. A rare and beautiful dahlia; good stems

UNCLE SAM ( $\mathbb{P}$ ) - A very large bloom; colon orange buff with a tint of pink; stems good; free blooming

U. S. A. (P.) - One of the finest dahlias in color, formation and size ever offered; a glorious hybrid cactus peony of a new, distinct shade of deep, bronzy orange. Blooms often 9 to 10 inches across and also very freely produced; stems tairly good_____.

VALIANT (Mnglish Cenc)-Dright crimson long narrow incurved petals; extra large blooms; on strong stems _-__.....-- - - -

*VALONA (Peony) - . Full fluify blooms of medium size on good stems; color rose pink blending lighter at tips. A beautiful cut flower and profuse bloomer.

VALI'ARATSo (Cac.)-Large, clear coral color on good stem; a beautiful flower

ITCAR OF WASPHETOS (WInlish Cac.) Beautiful pink with cream center and tips; very large and on good stems _.......--

VULCAN (English (aco)-Very large dark maroon with small florets at base of in-

- curving petals, giving flowel very unique appearance: good stems

IVALKTRE (Hyhoir (uctus)-Very large yel low deepening to gold at centel"; good stem.

WAL'ER: HAY (sh.) Color gold with r rerse of petals orange; stems good: fiter blooming
W. W. COOPER (Dec.) - A new California decorative with huge blossoms of clear, true pink without a tinge of mauve; stems erect and strong ...................

75 WWDDING DAY (P.)-Crimson shaded rose, edged and tipped white; very showy; good stems

WHITE CHAMPION (Cac.) - A new large white from Australia on good stems; a splendid flower

WHITE (OLOSSE (Dec.)-Very large and full flowers, white with light flesh tinge; very long, strong stems

WHITE SISTHR (Dec.)-The blooms are large and stems are good; free blooming; color white - -

WHISHIRE IENSIGN (Hybrid Cactus)Bright pink and white; good stem _.......

WIRARD OF OZ (Dec.)-This new introduction of gigantic size is indeed a "Wizard." The color is a rare shade of glowing amber pink, with soft salmon shades. Blooms often measure from 9 to 11 inches. The stens are erect and stout but short......

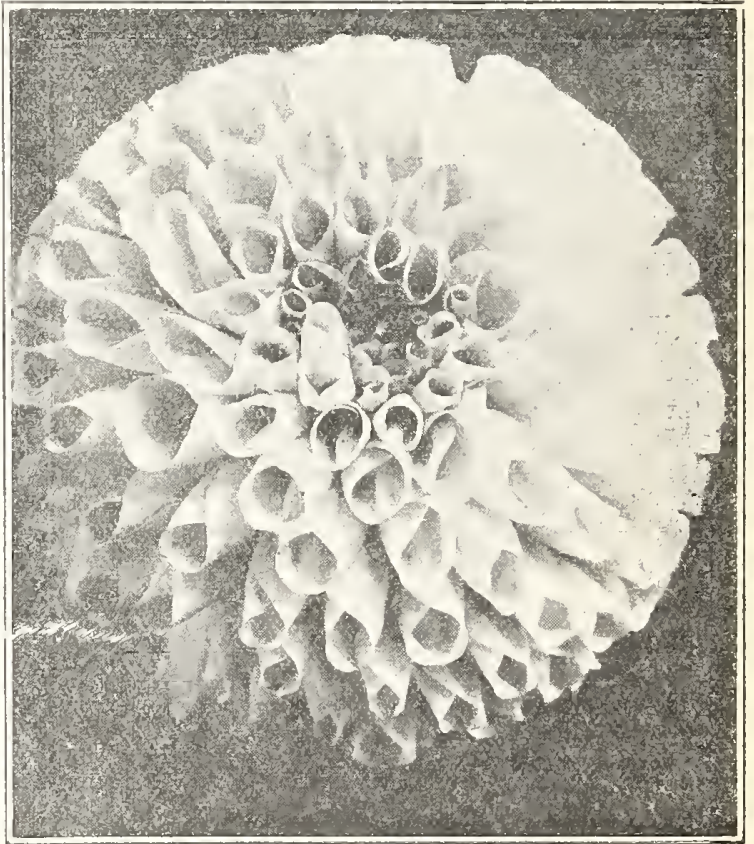

SHOW DAHLIA-W. IV. RAIVSON

W. Wr. Bawson (Sh.)-Tery large flowers of pure white tinted lavender; very free blooming and reliable; on good stems --_ ZOBrW (Hybrid show) (dee)-Large flowel on good lono stems; very profuse bloomer; color apricot butf with reverse of old rose; a beautiful coloring and good dahlia

reLIOIV KING (H. C.)-Immense sulphur vellow on fine stems

YCBAN (sh.) -Yellow, striped red; very large Hybrid and one of the best show dahlias; good stems
2.00 


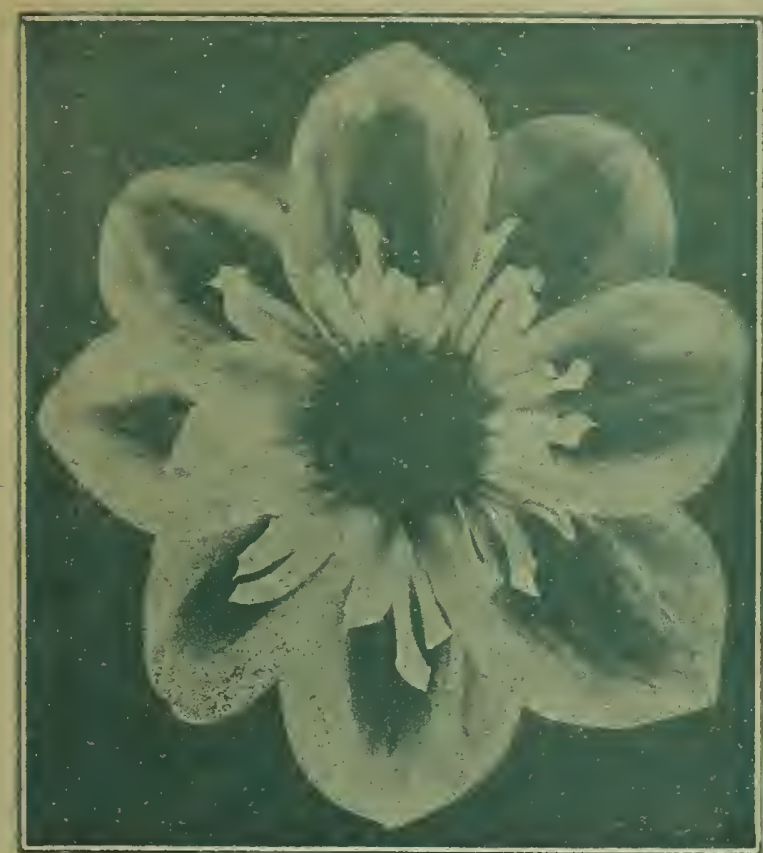

COLLARETIE DAHIIA

AMI CACHET-Orange red with good yellow collar; good stems

AMI NONIN - Rosy lilac, collar white; very large; on long stem.

- LEAH-Even visitors who were not admirers of this type had to stop and admire this gem. An extra large flower held erect on very stout stems. Deep crimson maroon, while the collar is white and maroon. Some flowers come varigated maroon and white_

SOUV. DE CHABANE-Bright yellow, fushed crimson, collar tipped white; very large---

SWALLOW-Beautiful pure white collarette; long, erect stems fine for cutting

- TELLOW BUTTERELY (Leo)-One of our new 1925 introductions; very bright canary yellow with yellow collar tipped lightly with white. Very beautiful. Good stems_-

\section{POMPONS DARILAS 25 Conts Each}

\$2.50 Per Dozen, Except Where Priced Amber Queen-Golden amber.

Annio Doncaster - Yellow base, suffused with pearly pink.

Baby-White, edged lavender.

Baby Evelyn (Leo)-New 1925 lovely solt salmon rose; very bautiful. $35 \mathrm{c}$.

- Beebe (Leo)-New 1925 bufr yellow tinted with liac rose.

Dr. Jim-Light ground, edged purple.

Dusky Babe (Lee) - New 1925 rich shade of crimson; very small. $35 \mathrm{c}$.

Trahion Sort orange.
Girlio-Pinkish mauve.

Geo. Ireland-A pretty mauve.

Glow-Charming old rose very small and neat. $50 \mathrm{c}$.

Jessica-Deep yellow, edged lightly with orange red.

Joe Fetto-A splendid new white. $35 \mathrm{c}$.

Kupfer-Salmon pink with tan. $35 \mathrm{c}$.

Lassio-Yellow base, tipped deep rose.

Little Beauty-A shrimp pink.

Little Beeswing-Golden yellow tipped deeply with cherry red.

Little Fred-Deep rose pink, small. $35 \mathrm{c}$.

Little Jennie-Primrose yellow.

Macbeth-White edged deep pink. $35 \mathrm{c}$.

Madelino-Pale yellow, edged purple.

Mrs. J. J. Kynn-Small, deep orange, 30c.

Phoebo-Deep yellow shaded orange.

Phylis-Yellow at base, tipped red.

Vivid-Very bright red.

Virida Flora-The green dahlia. The most unique novelty of dahlia culture. The flower is a rich verdant green, same shale as the loliage. $35 \mathrm{c}$.

\section{DAHLIA CULTURE}

The soil should be thoroughly cultivated and woll pulverized; then dig a good size hole and put In a shovel full of well rotted manure and work it up well with the soil; then cover with a little soil and lay bulb flat down with "eye" or sprout on top side, cover with $11 / 2$ inches of soll. After dahlia is up gradually fill up hole so that when soll is level the bulb will be covered 4 to 6 inches deep.

In planting in rows put $21 / 2$ to 3 feet apart. Whs cept Pompons, which can be planted $1 / 2$ to 2 feet apart.

Cultivation is most important. Keep them free from weeds and never allow the soll to crust. When you give them water, do it thoroughly and about once or twice a week.

For exhibition flowers, leave one stalk to bulb and tie it to stake set well in ground. When about 18 inches to two feet high, if they appear too bushy, trim out every other branch and when budded, where there are three or more buds, remove all but center bud. An application of manure, either in liquid or ordinary form sereral times throughout the blooming season ls very beneficial in raising large flowers.

When frost kills the tops, cut them of and lift bulbs very carefully and store in some dry place that is sure frost prool. Do not difide clumps till April, when you can see the "eyes" or sprouts and be sure to cut each bulb with a good "eye."

Plant only one bulb in hill and remember that a tuber as small as a peanut, with a good lire "eje," is as good or better than a very large one, as some varieties make very small bulbs, while others make very large ones.

Important-When you recelve your bulbs put them in a cool place and keep molst untll ready to plant eut. Don't let them dry out. 
PEINTING

SGINTING

TACOMA 